On the Front Line 



\section{ON THE FRONT LINE}

Organization of Work in the Information Economy

Stephen J. Frenkel MareK KorCZYNSKI

Karen A. Shire

MAY TAM

ILR PRESS

AN IMPRINT OF

CORNELL UNIVERSITY PRESS

Ithaca and London 
Copyright $(\odot 1999$ by Stephen J. Frenkel, Marek Korczynski, Karen A. Shire, and May Tam

All rights reserved. Except for brief quotations in a review, this book, or parts thereof, must not be reproduced in any form without permission in writing from the publisher. For information, address Cornell University Press, Sage House, 5 I 2 East State Street, Ithaca, New York I4850.

First published 1999 by Cornell University Press

First printing, Cornell Paperbacks, 1999

Cornell International Industrial and Labor Relations Report Number 35

Printed in the United States of America

Library of Congress Cataloging-in-Publication Data

On the front line: organization of work in the information economy /

Stephen J. Frenkel ... [et al.].

p. $\quad \mathrm{cm}$.

Includes bibliographical references and index.

ISBN o-80I4-3587-o (cloth: alk. paper).-ISBN o-8or 4-8567-3 (pbk: alk. paper)

I. Work. 2. Production management. 3. Industrial sociology.

4. Service industries. 5. Workflow systems-Case studies.

I. Frenkel, Stephen.

$\mathrm{HD}_{4904.0487} \mathrm{I} 999$

$306.3^{\prime} 6$ - dc2

$98-36539$

Cornell University Press strives to use environmentally responsible suppliers and materials to the fullest extent possible in the publishing of its books. Such materials include vegetablebased, low-VOC inks and acid-free papers that are recycled, totally chlorine-free, or partly composed of nonwood fibers. Books that bear the logo of the FSC (Forest Stewardship Council) use paper taken from forests that have been inspected and certified as meeting the highest standards for environmental and social responsibility. For further information, visit our website at www.cornellpress.cornell.edu.

Cloth printing Paperback printing

$\begin{array}{llllllllll}\text { IO } & 9 & 8 & 7 & 6 & 5 & 4 & 3 & 2 & \text { I } \\ \text { IO } & 9 & 8 & 7 & 6 & 5 & 4 & 3 & 2 & \text { I }\end{array}$

